\title{
Reproductive cycle of Mellita quinquiesperforata (Leske) (Echinodermata, Echinoidea) in two contrasting beach environments
}

\author{
Yara A. G. Tavares \& Carlos A. Borzone \\ Centro de Estudos do Mar, Universidade Federal do Paraná. Avenida Beira Mar, Caixa Postal 50002, 832555-000 Pontal do \\ Paraná, Paraná, Brasil. E-mail: ytavares@ufpr.br; capborza@ufpr.br
}

\begin{abstract}
The reproductive cycle of the irregular echinoid Mellita quinquiesperforata (Leske, 1778) was studied in populations from two sand beaches with different morphodynamic conditions in Parana coast, from February 1992 through July 1994. Gametogenesis was described by histological and gonad index methods and the differences between both populations were observed in the extension of nutrient storage and spawning period. Both populations exhibited a main reproductive period during spring/summer and a nutrient storage period during autumn/winter months. The spawning period at the intermediate-dissipative beach was shorter than at the reflective beach. Meanwhile, a nutrient storage stage was more extensive in the latter. Gonad index varied between both sexes and it was influenced by population characteristics. Different strategies in allocation of resources between maintenance and reproduction effort (oocyte size) confirm the high adaptive plasticity developed by this species to live in contrasting beach environments.
\end{abstract}

KEY WORDS. Reproductive plasticity; sand dollar; sandy beach.

\begin{abstract}
RESUMO. Reprodução de Mellita quinquiesperforata (Leske) (Echinodermata, Echinoidea) em dois ecossistemas praiais contrastantes. $\mathrm{O}$ ciclo reprodutivo do equinóide irregular Mellita quinquiesperforata (Leske, 1778) foi estudado em populações de duas praias com diferentes condições morfodinâmicas na costa paranaense, de fevereiro de 1992 a julho de 1994. A gametogênese foi descrita pela análise histológica das gônadas e pela variação do índice gonadal. Foram encontradas diferenças com relação à extensão do período de estocagem de nutrientes e do período de liberação dos gametas nas populações. Ambas exibiram um marcado período reprodutivo na primavera e no verão e uma época de estocagem de nutrientes no outono e no inverno. Na praia intermediária-dissipativa a liberação de gametas ocorreu num período menor do que na reflectiva, porém a fase de acúmulo de reservas nutritivas foi mais extensa na primeira. O índice gonadal apresentou variações entre os sexos e foi influenciado pelas características populacionais. As diferentes estratégias na alocação dos recursos entre manutenção e esforço reprodutivo (tamanho do ovócito) confirmam a elevada plasticidade adaptativa desenvolvida pela espécie para habitar ambientes praiais contrastantes.
\end{abstract}

PALAVRAS-CHAVES. Bolacha-da-praia; plasticidade reprodutiva; praia arenosa.

Mellita Klein, 1734, is a genus of clyperasteroid echinoids known as "sand dollars". Three allopatric Atlantic species were described (HAROLD \& TELFORD 1990): M. isometra Harold \& Telford, 1990, restricted to the east coast of North America (Massachusetts to Florida); M. tenuis Clark, 1940, found on the Gulf of Mexico and the type species, M. quinquiesperforata (Leske, 1778), that occurs from the Mississipi delta along the Central and South America coasts down to southern Brazil.

Mellita quinquiesperforata is an important component of Brazilian sandy beaches communities. Its populations occur in high densities in the infralittoral zone, where they are spatially aggregated forming a continuous bed parallel to the shoreline, in the proximity of breakers and behind a heavy wave action (BORZONE 1992). The extension and position of these beds have been associated with conditions of beach morphodynamics: a narrow bed occurred at the reflective morphodynamic extreme (sensu SHORT \& WRIGHT 1983) meanwhile large beds with great offshore extension were found at the dissipative extreme (BorzonE \& GiAnUCA 1990, Borzone et al. 1997, 1998, Borzone 1999, Barros et al. 2001).

Recent studies in other marine invertebrates living in sandy beaches, such as amphipods (Gomez \& Defeo 1999), anomura crustaceans (Dugan \& HubBard 1996) and polichaets (SOUZA \& Borzone 2000), suggested that features of population dynamics may be influenced by the morphodynamic beach type.

Reproductive characteristics of echinoids show variation in periodicity and intensity of spawning between years and populations. Environmental factors are considered important for the 
synchronization of gonadal activity, such as the gametogenesis cycle (Bentley 1998). Seawater temperature, photoperiod, food availability and lunar rhythms have been frequently suggested as exogenous cues affecting reproduction of species (LEssIos 1984, McClintock \& Watts 1990, Pearse \& Cameron 1991, Freire et al. 1992, Chen \& Chen 1993, Bentley 1998).

Studies on reproduction allow the construction of models relating life histories to reproduction and/or maintenance as a function of environmental characteristics (FreIre et al. 1992). For these purposes, the sand dollar Mellita quinquiesperforata seems a good subject allowing the understanding of how a species with a wide latitudinal distribution (occupying different environmental conditions) functions throughout its range. A few number of studies have investigated the process of reproduction in clyperasteroids (Lane \& Lawrence 1979, Chen \& Chen 1993, Vernon et al. 1993, Bentley 1998, Tavares \& Borzone 1998). Scarce works have examined the reproductive cycle of Mellita species. Gonadal growth, gametogenesis and gonad index of M. tenuis were studied on a shallow sublitoral sandy beach adjacent to Tampa Bay mouth (Florida) (Moss \& Lawrence 1972, Lane \& Lawrence 1979).

Recently, reproductive activity of $M$. quinquiesperforata was analyzed by Gonad index in two contrasting beach environments in the southern Brazilian coast (TAVAREs \& BORzone 1998). Salinity and beach morphodynamics were suggested as major environmental factors driving differences on the reproductive cycle in both hydrodynamic conditions. However, it is well known that interpretation of reproductive cycle from variation in gonad index may be biased especially in those animals that use gonads both for gametes and nutrient store. The present study reanalyzes those data by two ways: first recalculating gonad index distinguishing males from females, and second, through histological examinations of the gametogenesis process aiming at comparing methodologies in order to property ascertain differences between environments.

\section{MATERIAL AND METHODS}

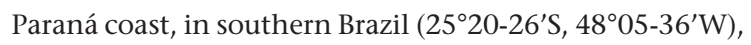
stretches for $100 \mathrm{~km}$ in a NE-SW direction. In the north, Mel Island divides the Paranaguá Bay estuarine system's access to the open sea. Below this access, Leste Coastal Plain is $30 \mathrm{~km}$ long and comprises only one beach with highly variable sand sediment and morphological characteristics throughout its extension. On this geographic area two localities have been chosen: Atami Beach - an open to the ocean beach $10 \mathrm{~km}$ south of Paranaguá Bay inlet (L1) - and Pontal do Sul Beach - a protected beach localized in front of Mel Island (L2) (Fig. 1).

Sediments from both beaches were composed of clean quartz sands, with fine material due to the proximity of an estuarine access. Water temperature presented similar variations with a seasonal south Atlantic pattern ranging from 15.0 to $28.5^{\circ} \mathrm{C}$ (August-March) and salinity was around 30.0 during the hole year. Morphodynamic indexes (Dean's and surf-scaling parameter) indicated great environmental differences be-

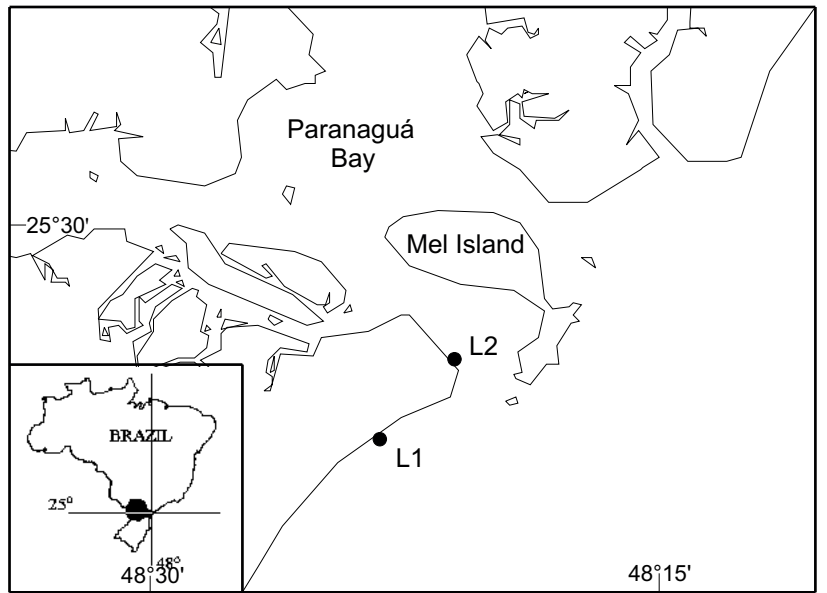

Figure 1. Localization of sampling area at southern Brazil. Locality 1 (L1): Atami Beach; Locality 2 (L2): Pontal do Sul Beach.

tween both localities. Atami beach presents a gentle beach profile and omega values varying from 2.6 to 12.4 , characteristic of intermediate to dissipative states. Values of the Surf scaling parameter, varying from 27.0 to 588.0 , indicates highly dissipative conditions in the surf zone for all observations. Small waves and a narrow surf-zone characterized Pontal do Sul beach. Omega values varied from 1.3 to 6.5 , with most of them less than two and suggesting a modal reflective state. Similarly, Surf scaling parameter's values ranged from 2.8 to 17.7 , being near reflective conditions. Other physical and sedimentological characteristics of these localities have already been described in previous works (TAVAREs \& BORZONE 1998).

Mellita quinquiesperforata specimens were sampled nearly monthly from February 1992 to July 1994 with one manually operated dredge $\left(0.25 \mathrm{~m}^{2}\right.$ surface area) by a scuba diver down to a depth of 3 meters at Atami Beach and from August 1993 to July 1994, using the same device but to a depth of $1.5 \mathrm{~m}$, at Pontal do Sul Beach. Twenty individuals larger than $40 \mathrm{~mm}$ in test width (maximal perpendicular distance to antero-posterior axis) were fixed in $10 \%$ formaline. Four gonads were removed, dried to $60^{\circ} \mathrm{C}$ to constant weight and weighted to $0.00001 \mathrm{~g}$. Gonad index (organ dry weight/body dry weight $\mathrm{x}$ 100) was calculated for each individual. For sexual determination and gametogenesis description, the remaining gonad was dehydrated, embedded in paraffin wax, sectioned at $7 \mu \mathrm{m}$ thickness, mounted and stained with hematoxylin and eosin. Images of histological sections were made using an optical microscope equipped with a photographic camera.

Sex ratio was determined for each locality and deviation of the relation male:female $(1: 1)$ tested by the statistical analysis of Chi-square $\left(\chi^{2}\right)$. Approximately 50 healthy oocytes were measured by the median diameter axis [(length + width) $\mathrm{x} 0.5$ ] with an ocular micrometer. Frequency distribution of the oocyte diameter was calculated for each sample/place. 


\section{RESULTS}

\section{Sex ratio}

A total of 538 individuals were collected during 22 sampling months on Atami Beach (172 males and 173 females) and 11 months on Pontal do Sul Beach (104 males and 89 females). Both populations showed no significant difference from the $1: 1$ sex ratio $\left(\chi^{2}=2.05, \mathrm{p}<0.9999 ; \chi^{2}=1.20, \mathrm{p}<0.9995\right.$, respectively).

\section{Histological analysis}

According to previous authors (FujI 1960, LANE \& LAWRENCE 1979, LaegdsgaARd et al. 1991, Bentley 1998), five stages were established to characterize the process of gametogenesis in Mellita quinquiesperforata:

Growing/developing or proliferative stage (Figs 2 and 3): gonad lumen were still filled with nutritive phagocytes. In females, pre and early vitellogenic oocytes have an irregular shape contour and appear attached to the tube wall. Some solitary vitellogenic oocytes move away from the wall and occupied the center of tube lumen among nutritive phagocytes. In males, primary sexual cells (spermatogonia and spermatocyte) occurred as a band close to the tube wall. Few or any spermatozoa occur at the center of the tube rounded by nutritive phagocytes.

Premature stage (Figs 4 and 5): a great number of advanced vitelogenic or mature oocytes are present, although numerous early vitelogenic oocytes are still present at the tube wall. Nutritive phagocytes were closed between tube wall and lumen. In males, primary sexual cells form a narrow band close to the tube wall meanwhile mature spermatozoa fill the center of the tube lumen. As in females, nutritive phagocytes occupied a peripheral position.

Mature stage (Figs 6 and 7): most of the ovarian lumen are filled by mature gametes with poligonal shape that exhibit a great number of cortical granules at their surface. Few primary oocytes are found and nutritive phagocytes cells are rare or absent. In males, most of the tube lumen is filled by mature spermatozoa. A straight band of primary cells are still present but nutritive phagocytes are absent.

Depletion/spent stage (Fig. 8): few relict oocyte/spermatozoa may be found in a reduced tube lumen within sparse nutritive phagocytes. Phagocytosis is evidenced by the presence of strong basophilic agglutination structures. In some male gonads, tubes showed a mixture of nutritive phagocytes, primary cells and spermatozoa.

Resting stage (Fig. 9): whole tube is filled by nutritive phagocytes. Few, if any, sexual cells are attached to the tube wall. Sex may be identified with some uncertainty by the particular characteristic of nutritive phagocytes (more dense and with greater granules in females) or by finding any of the rare sexual cell present throughout the whole slide.

\section{Reproductive cycle}

Female reproductive cycle at Atami Beach showed more than $60 \%$ of the individuals at proliferative stage at the end of winter and spring months (July 1992, November 1992, September 1993). Premature and mature stages (50-80\% approximately) occurred mainly during summer months (March and December 1992, February 1993, January 1994) and a resting stage appeared in autumn months (April 1992 and May 1993, 1994), extending into winter months (July 1992, June and July 1994) when most of the females (50-90\%) exhibited a great nutrient storage in their gonads (Fig. 10). At Pontal do Sul Beach premature and mature stage occurred in more than $60 \%$ of the females during summer, autumn and winter months (from December 1993 to July 1994). In contrast, resting stage appeared in a few individuals (10-20\%) in autumn and winter months (May to July 1994) (Fig. 11).

Male cycle accompanied the female pattern. Meanwhile, greater differences between both sites have been found for the occurrence of the mature stage, which was reduced to a few months at Atami Beach (October 1993 and February-March 1994) (Fig. 12) and extended to almost the entire year at Pontal do Sul Beach (from October 1993 to May 1994) (Fig. 13).

\section{Gonad index}

Female gonad index (GI) variation at Atami beach was significant $(\mathrm{F}=3.85, \mathrm{p}=0.0002)$ and ranged from $1.30 \%$ (September 1993) to $0.36 \%$ (April 1994). GI values decreased significantly twice during the year: in spring (September and October 1993) and in the end of summer (March to April 1994) (Fig. 14). Males GI variation was also significant $(\mathrm{F}=5.43, \mathrm{p}=$ 0.0001 ) and ranged from $1.20 \%$ (September 1994) to $0.44 \%$ (June 1994). In this case, GI values rise in spring (August to October 1993) and decreased smoothly along the rest of the sampling period (Fig. 16).

There was no difference on female GI values during the sampling period at Pontal do Sul Beach. Gonad index varied from $1.09 \%$ (February 1994) to $0.53 \%$ (June 1994) (Fig. 15). On the other hand, male GI variation was significant $(\mathrm{F}=3.91, \mathrm{p}=$ 0.0001 ) and ranged from $0.56 \%$ (October 1993) to $1.52 \%$ (February 1994). Highest GI values were registered during summer months (January to March 1994), and only one significant decrease has been registered from summer to autumn (February to April 1994) (Fig. 17).

\section{Oocyte growth}

At Atami Beach sequences of oocyte growth were registered in summer (January to March 1993/1994) and spring (August to October 1994). Mean modal diameter of mature oocyte ranged from 75 to $90 \mu \mathrm{m}$, and maximal values of $115 \mu \mathrm{m}$ were found in March 1994. A period without oocytes occurred from autumn to winter (May to July 1994) (Fig. 18).

At Pontal do Sul Beach mature oocyte modals were found all over the sampling period. Mean values ranged from 80 to $115 \mathrm{~mm}$, and higher mean modal values of $100 \mu \mathrm{m}$ were registered from the end of summer to autumn (February to May 1994). Several months presented values below $110 \mu \mathrm{m}$, and oocytes were absent in only one month (July 1994) (Fig. 19).

Revista Brasileira de Zoologia 23 (2): 573-580, junho 2006 

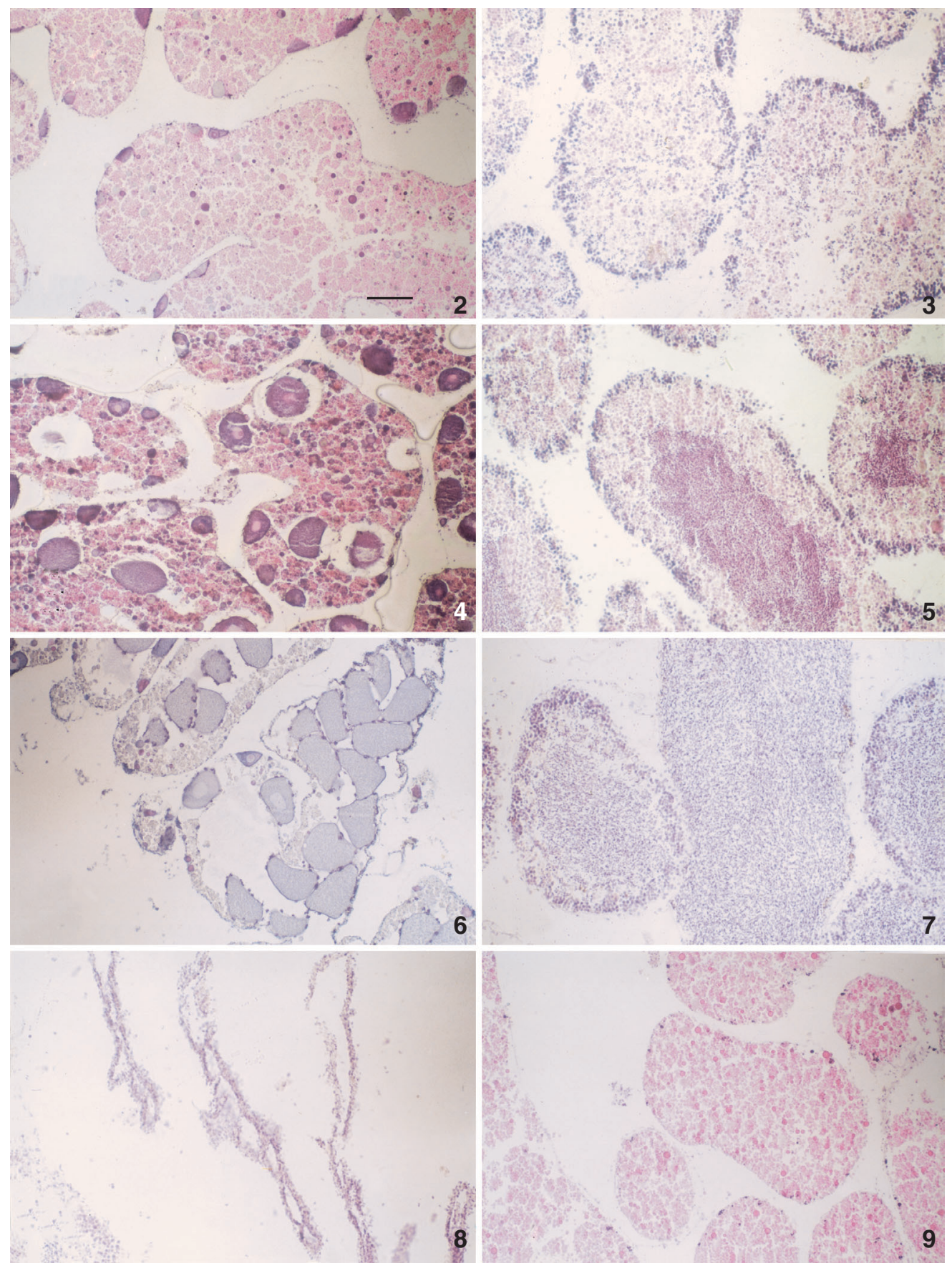

Figures 2-9. Gametogenesis stages in Mellita quinquiesperforata. (2) Female proliferative stage: lumen filled by nutritive phagocytes, early vitellogenic oocytes with irregular shape contour; (3) Male proliferative stage: primary sexual cells occurred as a band close to tube wall, few or rare spermatozoa at the center of tube lumen; (4) Female premature stage: advanced vitellogenic or mature oocytes; (5) Male premature stage: center of tube lumen with mature spermatozoa, nutritive tissue in a peripheral position; (6) Female mature stage: ovarian lumen filled with mature oocytes with cortical granules; (7) Male mature stage: most of tube lumen filled with mature spermatozoa; (8) Depletion stage: few mature oocyte/spermatozoa occupying a reduced lumen, phagocytosis of relict material is evident; (9) Resting stage: lumen filled with nutritive tissue, sex may be identified with some uncertainty. The horizontal bar in photographs (2) represents $100 \mathrm{~mm}$ and applies to all photographs. 

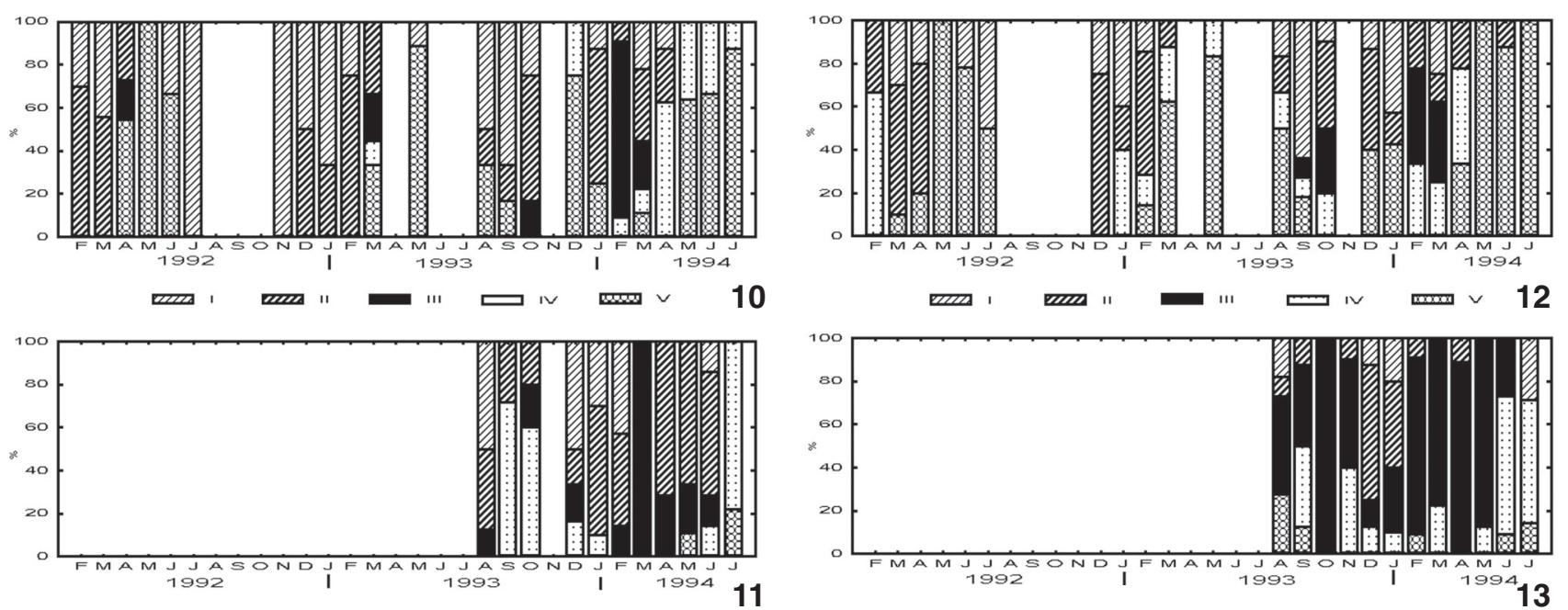

Figures 10-13. Percentage of gametogenesis stages. (10-11) Females: (10) Atami Beach, (11) Pontal do Sul Beach; (12-13) males: (12) Atami Beach, (13) Pontal do Sul Beach.
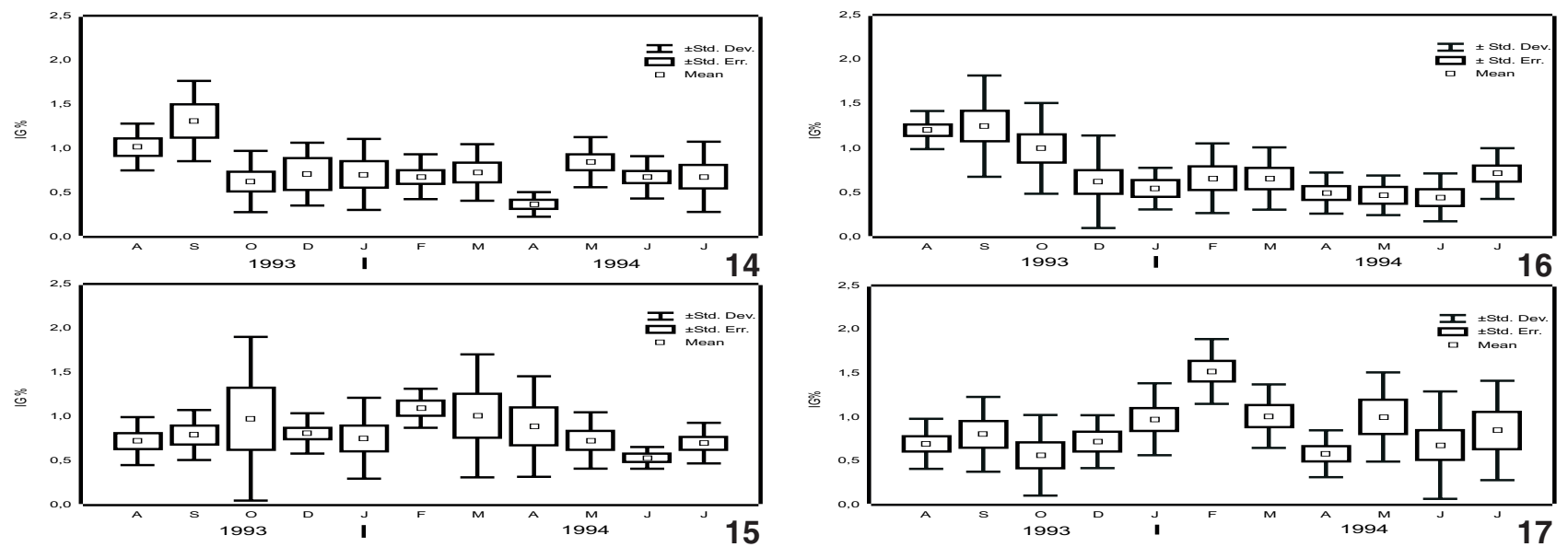

Figures 14-17. Gonad index variation. (14-15) Females: (14) Atami Beach, (15) Pontal do Sul Beach; (16-17) males: (16) Atami Beach, (17) Pontal do Sul Beach.

\section{DISCUSSION}

Intraspecific reproductive variability occurs among both geographically separated populations and proximal populations inhabiting heterogeneous environments. The amount of intraspecific plasticity may be the results of genetic divergence, phenotypic adaptation to external stimuli, or both (ERNEST \& BLAKE 1981). In this contribution, proximal sand dollar populations inhabiting morphodynamically different sandy beach environments showed some differences on the reproductive pattern related to the extension of nutrient storage and spawning period. Both populations exhibited a main reproductive period during spring/summer and a nutrient storage period during autumn/winter months, although in the population at Atami Beach mature individuals were found in a few months and a great nutrient storage stage was more extensive. Otherwise, the population at Pontal do Sul Beach showed a maturation stage during almost the entire year, and a process of nutrient accumulation occurred in scarce individuals during some winter months.

Other studies on M. quinquesperforata population dynamics have revealed latitudinal variations in the recruitment pattern of this species. Borzone (1992) found an important recruitment between autumn and winter at an extensive exposed sandy beach at Rio Grande do Sul (Brazil). At Atami Beach, an extensive recruitment period from the end of winter to summer was registered (TAVARES \& BORZONe 1998). For another population in Quizandal Beach (Venezuela), Penchaszadeh \& Molinet (1994) found a constant recruitment of juveniles during the entire year with a maximum peak in spring and summer months.

Revista Brasileira de Zoologia 23 (2): 573-580, junho 2006 

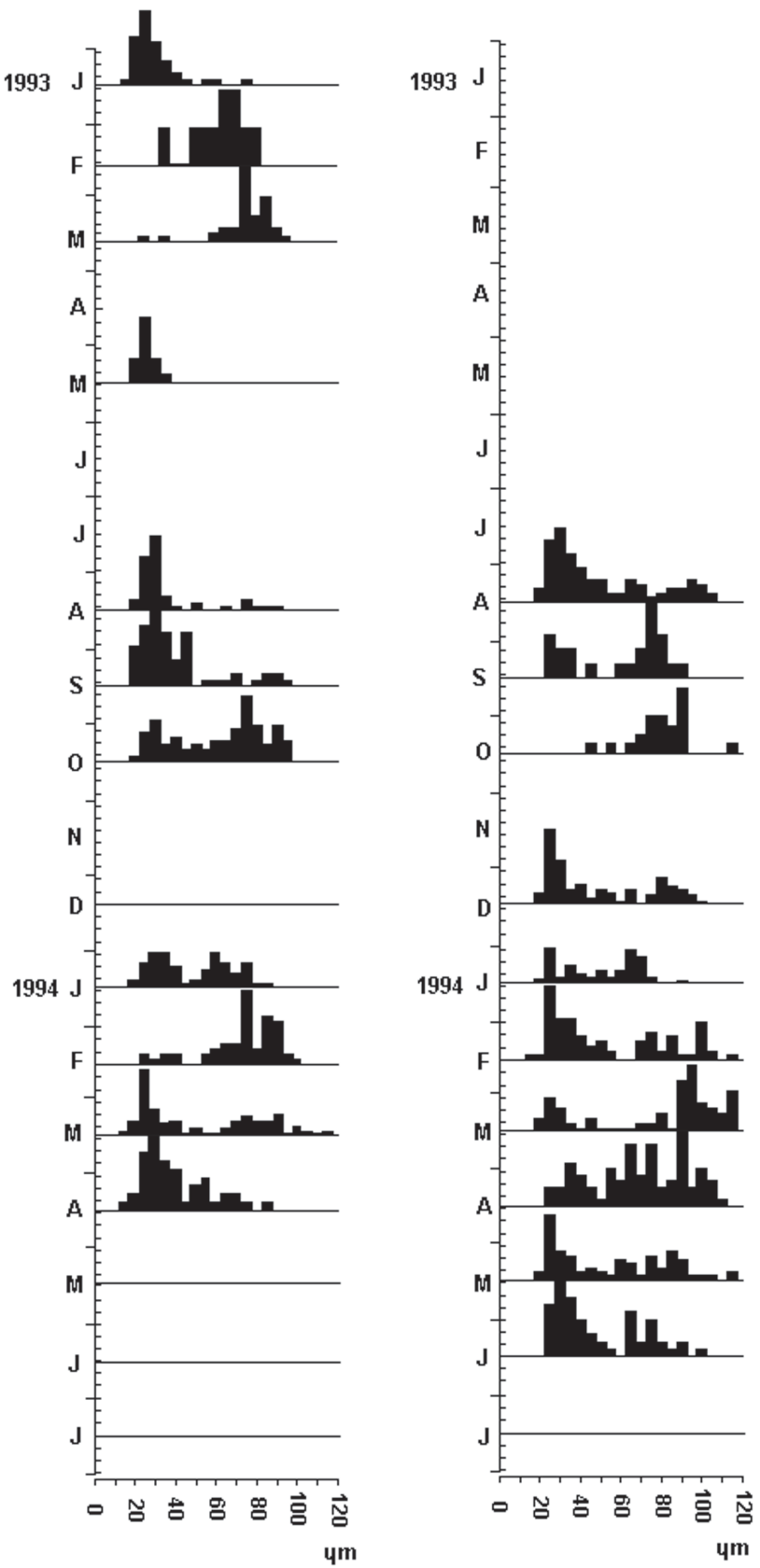

Figures 18-19. Size-frequency distribution (oocyte diameter): (18) Atami Beach, (19) Pontal do Sul Beach.

In spite of present result showed a more extended reproductive period at Pontal do Sul Beach, no recruitment had been registered during the studied period (TAVAREs \& Borzone 1998). In a reflective beach, with a narrow surf-zone, adults occupy the whole habitat and probably excluded new recruits. In an intermediate-dissipative beach, as Atami Beach, an extensive surf zone favored spatial segregation between adults and recruits, allowing occurrences of recruitment.

Reproduction in sea urchins involves nutrient accumulation in the gonads, which occurs into especially adapted storage cells (nutritive phagocytes) (ERnest \& Blake 1981). These cells may occur prior to or during gametogenesis, but mainly during the post-spawning period involving a "resting phase". Consequently, most of gonad size increase could be explained by nutrient accumulation. Organ indices, such as Gonad index (GI) may be strongly influenced by the resource allocation strategy and its efficiency had already been discussed by many authors (Grant \& Tyler 1983, Vernon et al. 1993, Chen \& Chen 1993). For example, in Mellita tenuis, LANE \& Lawrence (1979) verified that an increase in gonadal indices during summer was in part related to nutrient accumulation of individuals two or more years old.

In the present work, the GI spring peak at Atami Beach was a consequence of both resource allocation and proliferative growth, and only the GI summer peak represented a maturation stage. At Pontal do Sul Beach a more extended reproductive period probably attenuated female GI variation, but male GI showed a clear variation, with higher values in summer that really represented a greater number of mature individuals.

Lane \& Lawrence (1979) and Penchaszadeh \& Molinet (1994) had already suggested a difference in reproductive strategies in Mellita species with respect to the period of storage and timing of spawning. When a brief nutritive accumulation cycle occurs the population can release its gametes continually. In contrast, when a larger allocation of resources is required in function of environmental stress, exists a reduction of reproductive activity.

Energy allocation should be separated between somatic growth, maintenance and reproductive effort. Life history strategies are characterized by difference on the energy allocation for these physiological requirements. In the Mellita species the gut is less prominent than in other urchins. In this case, gonads could serve as the primary reserve organ of the animal for both gametogenesis and periods of starvation or high-energy demands (Moss \& Lawrence 1972). The sand dollar preference for living close to shore in the proximity of breakers or in locals with hardness of environment determined great resource allocations to maintenance and in consequences less to growth and reproduction (Borzone 1992). The development of an energetic storage phase to allocate resource was described for Mellita tenuis. In this species, peaks in the biochemical constituents (lipid, protein) of gonads prior to gametogenesis were associated to periods of starvation due to severe winter storms, when individuals were completely buried and its lunules become clogged and feeding ceases (Moss \& LAWRENCE 1972).

Our results have revealed that the greater period of storage developed by the sand dollar population at the intermediate-dissipative beach was associated to a strong wave action 
during winter, when more energy was devoted to maintenance. At the reflective beach, with less severe hydrodynamic condition, this period was reduced and resources could be employed to reproduction the whole year long.

Egg size of marine invertebrate is another life history parameter related to mode of development and allocation of resources (Lessios 1987). During favorable conditions, when cost of maintenance is reduced, resource allocations may be devoted to transfer the maximum of energy to gametes. This hypothesis can explain the difference in oocyte size found in the present study between both populations. Average mature oocyte diameter in Atami Beach showed smaller values in a shorter range, while in Pontal do Sul Beach values were greater and in a larger range.

Finally, our results suggested that in Mellita quinquiesperforata populations, environmental factors can act over physiological demands. In addition, it confirms the higher adaptive plasticity of this species to choose the better strategy to drive its life history.

\section{ACKNOWLEDGEMENTS}

We wish to thank two anonymous referees for their suggestion and grammatical revision.

\section{REFERENCES}

Barros JR., F.C.R.; C.A. Borzone \& S. Rosso. 2001. The macroinfauna of six beaches near Guaratuba Bay, Southern Brazil. Brazilian Archives of Biology and Technology, Curitiba, 44 (4): 351-364.

Bentley, A.C. 1998. Reproductive cycle and gonadal histology of Echinodiscus bisperforatus along the southern coast of South Africa, p. 571-576. In: R. Moor \& M. TElford (Eds). Proceedings of the $9^{\text {th }}$ International Conference of Echinoderms. Balkema, Rotterdam.

Borzone, C.A. 1992. Spatial distribution and growth of Mellita quinquiesperforata Leske, 1778 on a sandy beach of southern Brazil. Nerítica, Curitiba, 7 (1-2): 87-100. [1993]

Borzone, C.A. 1999. Influence of Mellita quinquiesperforata beds on the structure of subtidal benthic communities of sandy beaches, p. 433-438. In: M.D.C. CARnevali \& F. Bonasoro (Eds). Proceedings of the $5^{\text {th }}$ European Conference of Echinoderms. Balkema, Rotterdam.

Borzone, C.A. \& N.M. GianuCA. 1990. A zonação infralitoral em praias arenosas expostas, p. 280-296. In: Anais do II Simpósio de Ecossistemas da Costa Sul e Sudeste Brasileira. São Paulo, Publicações Aciesp, vol. 3.

Borzone, C.A.; Y.A.G. Tavares \& C.R. SoARes. 1997. Adaptação morfológica de Mellita quinquiesperforata (Clypeasteroida, Mellitidae) para explorar ambientes com alto hidrodinamismo. Iheringia, Série Zoologia, Porto Alegre, 82: 33-42.

Borzone, C.A.; Y.A.G.; tavares \& F.C.R. Barros Jr. 1998. Beach morphodynamics and distribution of Mellita quinquies- perforata Leske, 1778 on sandy beaches of southern Brazil, p. 581-586. In: R. Moor \& M. TElford (Eds). Proceedings of the $9^{\text {th }}$ International Conference of Echinoderms. Balkema, Rotterdam.

Chen, B.Y. \& C.P. Chen. 1993. Reproduction and development of a miniature sand dollar, Sinaechinocyamus mai (Echinodermata: Echinoidea) in Taiwan. Bulletin of the Institute of Zoology Academia Sinica, Taipei, 32 (2): 100-110.

Dugan, J.E. \& D.M. Hubbar. 1996. Local variation in populations of the sand crab Emerita analoga (Stimpson), on sandy beaches in southern California. Revista Chilena de Historia Natural, Santiago, 69: 579-588.

ERnest, R.G. \& N.J. Blake. 1981. Reproductive patterns within sub-populations of Lytechinus variegatus (Lamarck) (Echinodermata: Echinoidea). Journal of Experimental Marine Biology and Ecology, Amsterdam, 55: 25-37

Freire, C.A.; P.J.P. Santos; N.F. Fontoura, R.A.; O. Magalhães \& P.A. Grohmann. 1992. Growth and spatial distribution of Cassidulus mitis (Echinodermata, Echinoidea) on a sandy beach in southeastern Brazil. Marine Biology, Berlin, 112: 625-630.

FujI, A. 1960. Studies on the biology of the sea urchin. I - Superficial and histological gonadal changes in the gametogenic process of two urchins Strongylocentrotus nudus and $S$. intermedius. Bulletin of the Faculty of Fisheries Hokkaido University, Hakodate, 11: 1-14.

Gomez, J. \& O. Defeo. 1999. Life history of the sandhopper Pseudorchestoidea brasiliensis (Amphipoda) in sandy beaches with contrasting morphodynamics. Marine Ecology Progress Series, Oldendorf, 182: 209-220.

Grant, A. \& P.A. Tyler. 1983. The analysis of data in studies of invertebrate reproduction. I. Introduction and statistical analysis of gonad indices and maturity indices. International Journal of Invertebrate Reproduction, Amsterdam, 6: 259-269

Harold, A.S. \& M. Telford. 1990. Systematics, phylogeny and biogeography of the genus Mellilta (Echinoidea: Clypeasteroida). Journal of Natural History, London, 24: 987-1026.

LaEgdsgaARd, P.; M. Byrne \& D.T. Anderson. 1991. Reproduction of sympatric populations of Heliocidaris erythrogramma and H. tuberculata (Echinoidea) in New Wales (Australia). Marine Biology, Berlin, 110 (3): 359-374.

Lane, J.E.M. \& J.M. Lawrence.1979. Gonadal growth and gametogenesis in the sand dollar Mellita quinquiesperforta Leske, 1778. Marine Biology, Berlin, 38: 271-285.

Lessios, H.A. 1984. Annual reproductive periodicity in eight echinoid species on the Caribbean coast of Panama, p. 303311. B.F. Keegan \& D.D.S. O'Connor (Eds). Proceedings of the $5^{\text {th }}$ International Conference of Echinoderms. Balkema, Rotterdam.

Lessios, H.A. 1987. Temporal and spatial variation in egg size of 13 Panamanian echinoids. Journal of Experimental Marine Biology and Ecology, Amsterdam, 114: 217-239.

McClintock, J.B. \& S.A. WatTs. 1990. The effects of photoperiod 
on gametogenesis in the tropical sea urchin Eucidaris tribuloides (Lamarck) (Echinodermata: Echinoidea). Journal of Experimental Marine Biology and Ecology, Amsterdam, 139: 175-184.

Moss, J.W. \& J.M. Lawrence. 1972. Changes in carbohydrate, lipid and protein levels with age and season in the sand dollar Mellita quinquiesperforata (Leske). Marine Ecology Progress Series, Oldendorf, 8: 225-239.

Pearse, J.S. \& R.A. Cameron. 1991. Echinodermata: Echinoidea, p. 513-662. In: J.S. Pearse; V. Pearse \& A.C. Giese (Eds). Reproduction of Marine Invertebrates: Lophophorates and Echinoderms. Boxwood Press, California, 663p.

Penchaszadeh, P.E. \& R. Molinet. 1994. Population ecology of the sand dollar Mellita quinquiesperforata latiambulacra (Clark, 1840) on the west-central coast of Venezuela, p. 827-835. B. David; A. Guille; J.P. Féral \& M. Roul (Eds). Proceedings of the $8^{\text {th }}$ International Conference of Echinoderms. Balkema, Rotterdam.

Received in 24.VI.2005; accepted in 20.IV.2006.
Short, A.D. \& L.D. Wright. 1983. Physical variability of sandy beaches, p. 133-144. In: A. McLachlan \& T. Erasmus (Eds). Sandy Beaches as Ecosystems. The Hague, W. Junk, 765p. SouzA, J.R.B. \& C.A. Borzone. 2000. Populations dynamics and secondary production in a sandy beach population of Scolelepis squamata (Polychaeta:Spionidae). Bulletin of Marine Science, Lawrence, 67 (1): 221-231.

Tavares, Y.A.G. \& C.A. Borzone. 1998. General features of population dynamics of the sand dollar Mellita quinquiesperforata (Leske, 1778) in southern Brazilian sandy beaches, p. 837-842. In: R. Moor \& M. Telford (Eds). Proceedings of the $9^{\text {th }}$ International Conference of Echinoderms. Balkema, Rotterdam.

Vernon, J.D.; J.B. Mcclintock; T.S. Hopkins; S.A. WatTs \& K.R. MARION. 1993. Reproduction of Clypeaster ravenelli (Echinodermata: Echinoidea) in the northen Gulf of Mexico. International Journal of Invertebrate Reproduction and Development, Amsterdam, 24 (1): 71-78. 